\title{
Experience in designing and operating the buildings located on subsiding and heaving soils of the Minusinsk Hollows
}

\author{
Dmitry Strelnikov* and Oleg Khalimov \\ Khakas Technical Institute - SFU branch, Komarova 15, Abakan 655016 Russian Federation
}

\begin{abstract}
The article presents the experience of design, expert research within the period of construction and operation of the buildings located on subsiding soils. It describes the experiment in conducting the organized soaking of a mounted house made of reinforced-concrete slabs and claydite-concrete panels. It shows the absence of danger of frost heaving while soaking the subsiding soils. There are tables demonstrating the expert studies during the inspections of deformable buildings and longterm observations over their behavior in freezing and thawing depending on the groundwater level and pressures under the bottom of the foundations. As a result of the analysis of long-term studies it has been established that the building load contributes to the reduction of frost heaving for sandy soils (fine and dust sands). In case of clayey soils, in contrast to the views on this problem emerged at the end of the 20th century, it is impossible to extinguish the migration process using pressure. If the migration flow slows down under the foundation bottom, it occurs due to the higher rate of soil freezing arising from the high thermal conductivity of the foundation body and the formation of vertical ice lenses on the borders of tension zones. The most important thing showed herein is that the thawing process in these lenses provokes the process of stability loss, where the soil protrudes from the foundation bottom. The long-term studies of frost heaving in a severe continental climate of the Minusinsk hollows enabled the development of the most effective direction of the anti-heave stabilization.
\end{abstract}

\section{Introduction}

The Minusinsk Hollows are located between the mountains: Kuznetskiy Alatau on the west, the spurs of the Western Sayan on the South, the ridges of the Eastern Sayan on the east and the foothills of the Eastern Sayan and Kuznetsk Alatau on the north. The Yenisei, Abakan, and Tuba rivers play a significant role in the formation of the modern relief of the South Minusinsk Hollows. So do the Syda and Erba rivers for the formation of the MidMinusinsk Hollow and the Bely and Cherny Iyus and Chulym rivers - for the North Minusinsk Hollow [1, 2].

\footnotetext{
* Corresponding author: Lacky_traine@ mail.ru
} 
The climate of the region is severe continental with warm summers and cold winters. The average annual temperature varies from -0.5 to $+2.0^{\circ} \mathrm{C}$. The temperature in the intermontain basins is lower as compared to that of the surrounding mountain slopes, since the cold air flows down the slopes and stagnates in the basins.

In this regard, the low temperatures and the shallow snow cover contribute to the deep freezing of the soils. However, these are not only low temperatures which change its structure, but also a high wind [3,4].

The origin of the soils prone to subsidence, as a rule, is wind erosion. The capacity of the subsiding soils varies from 2 to 20 meters. So, for example, in the most developing cities of Abakan and Chernogorsk, the subsiding depth does not exceed two meters. However, in Chernogorsk there are areas with fault lines, filled with aeolian deposits to the depth of 18 meters.

In the eastern part of the Minusinsk Hollow, in the Minusinsk, Idrinsky, Karatuzsky, Shushensky districts, the depth of the subsidence varies from 8 to 15 meters. The scheme is shown on Figure 1 [5].

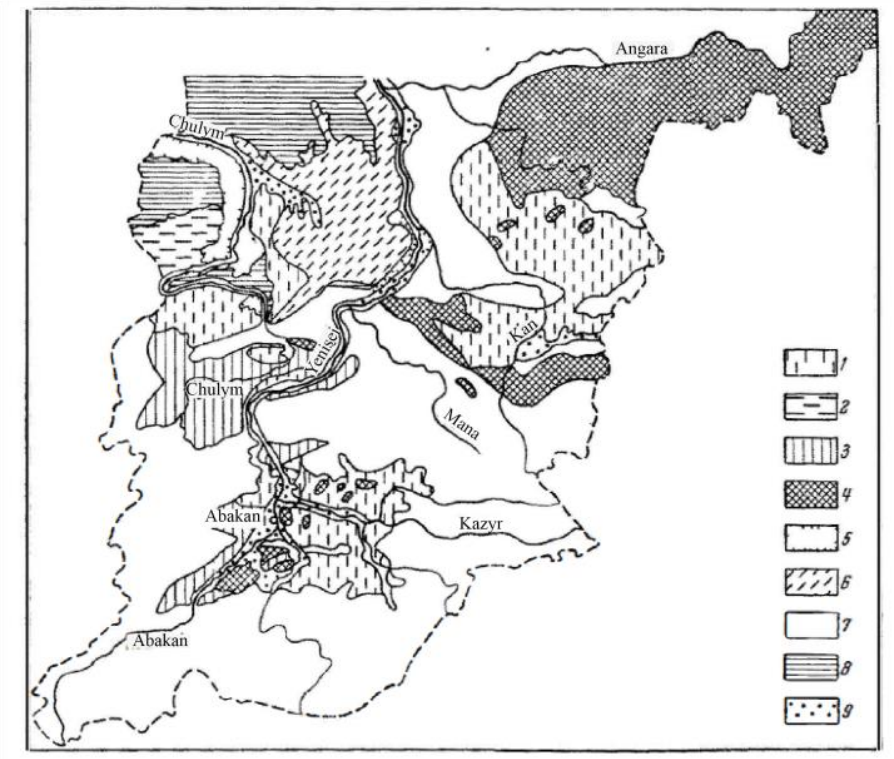

1 - Glaciofluvial loess deposits in the limits of the Minusinsk and Rybinsk Hollows; 2 - Glaciofluvial and lacustrine alluvial heavy loess loams and clays in the limits of the West Siberian Plain; 3- Deluvial and proluvial deposits of gentle slopes of cuesta and intracuesta depressions (Chebakovo Balakhtinskaya,Syrdo-Erbinskaya Depressions); 4 - Sporadic expansion of shallow eluvial and deluvial loess deposits (peripheral areas of the Minusinsk Hollows and Siberian Plateau); 5 -Alluvial loess deposits of vast river valleys; 6 - Wide loess loams on the slopes of the northern exposure (southeastern
part of the West Siberian Plain); 7 -Mountain structures of the Eastern and Western Sayan, the Kuznetskiy Alatau Range part of the West Siberian Plain); 7 - Mountain structures of the Eastern and Western Sayan, the Kuznetskiy Alatau Range
and the Yenisei Ridge having no loess layer; 8 - Non-loess heavy loams and clays on the territory of the Chulym-Yenisei Syneclise; 9 -Alluvial sandy and gravel-cobble deposits of the river valleys

Fig. 1. The location map of loess rocks in the southern part of the Krasnoyarsk territory

The relevance of the topic is determined by the needs of the foundations design practice, where the fear of these specific soils leads designers to the use of driven piles. However, such costly solutions can be eliminated by applying anti-heave and anti-subsiding stabilization. But its implementation requires a continuous improvement of both research technology (from models to production experiments) and the promotion of innovation into design practice using the geotechnical consulting at all stages of the building life cycle. 


\section{Example of improving the design of buildings located on subsiding soils}

Khakas Technical Institute has experience in the design, construction and operation of single-storey buildings made of reinforced concrete slabs and claydite-concrete panels in the village Solontsy of the city of Krasnoyarsk.

The subsidence column in this village varies from 5 to 12 meters. The value of subsidence of gravity load while soaking according to calculations in the lower, most powerful layer of subsiding soils reaches up to $15 \mathrm{~cm}$.

In accordance with the design solution, it was necessary to load 12-gauge piles with making pilot holes (Figure 2).

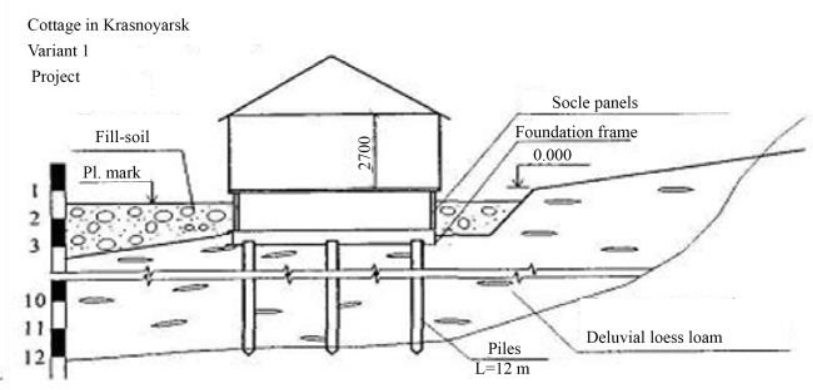

Fig. 2. Original version proposed by the design institute

However, the customer agreed to the proposal of Khakas Technical Institute and implemented an organized soaking method, which reduced the time and cost of construction (Figure 3).

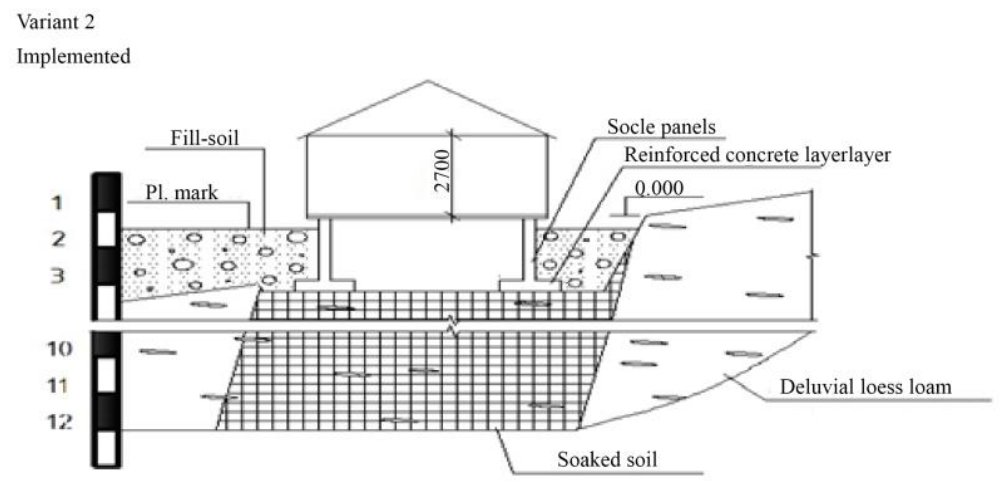

Fig. 3. Implemented version of construction with method of soils soaking

The houses were built according to the following technology: erection of strip foundations on the natural base, installation of basement panels, floors above the basement, walls of the first floor, floors above the first floor and a roof. After that, the base soils were soaked by pouring water into the basement. The infiltration occurred due to the infiltration of water without drilling the pilot holes and filling the sand into them, as later was required by the standards for carrying out the procedure of organized soaking.

All the works were carried out in 1982. The deformations of the unfinished objects were as follows: at the house located down the slope $-152 \mathrm{~mm}$, at the house located forty meters up the slope $-127 \mathrm{~mm}$. 
The deformations from soaking under the load from the structures of a dwelling house without the imposed load (from people, equipment, materials used in the functional process) were homogeneous. The existing cracks in the concrete-enveloped joints of the panels did not open. The drawbacks were that the porch dropped one step down and the zero mark occurred in relation to the planned mark.

Thirty-six years of operation of these houses have shown the working capacity of the foundation soils. There have been no deformations reducing the reliability of the supporting structures. However, this method of organized or regulated soaking has not yet been adopted either in Krasnoyarsk or in the south of the Krasnoyarsk Territory. At the same time, the entrepreneurs, who do not want to bury money in the foundations, are considering more rational options for building foundations on the subsiding soils.

While conducting a survey in the Shushensky district, the subsiding soils were found and then investigated and the results obtained are presented in Table 1.

Table 1. Calculation of the type of soil conditions for subsidence

\begin{tabular}{|c|c|c|c|c|c|c|c|c|}
\hline \multirow{2}{*}{$\begin{array}{c}\text { Depth } \\
\text { of soil } \\
\text { sampl- } \\
\text { ing }\end{array}$} & $\begin{array}{c}\text { Value of relative } \\
\text { subsidence under }\end{array}$ & $\begin{array}{c}\text { Consis- } \\
\text { tency } \\
\text { of water- } \\
\text { deposited } \\
\text { soil t/m }\end{array}$ & $\begin{array}{c}\text { Natural } \\
\text { pressure, } \\
\mathrm{mPa}\end{array}$ & $\begin{array}{c}\text { Relative } \\
\text { subsidence } \\
\text { under natural } \\
\text { pressure, } \varepsilon s l\end{array}$ & $\begin{array}{c}\text { Strength } \\
\text { of layer }\end{array}$ & $\begin{array}{c}\text { Subsi- } \\
\text { dence }\end{array}$ & $\begin{array}{c}\text { Initial } \\
\text { subsidence } \\
\text { pressure, Psl }\end{array}$ \\
\hline 2,0 & 0,039 & 0,048 & 1,89 & 0,038 & 0,012 & 2,00 & 0,024 & 0,033 \\
\hline 3,0 & 0,039 & 0,047 & 1,87 & 0,057 & 0,012 & 1,00 & 0,012 & 0,045 \\
\hline 4,0 & 0,039 & 0,050 & 1,88 & 0,076 & 0,018 & 1,00 & 0,018 & 0,033 \\
\hline 5,0 & 0,035 & 0,046 & 1,88 & 0,095 & 0,018 & 1,00 & 0,018 & 0,043 \\
\hline 6,0 & 0,032 & 0,040 & 1,87 & 0,114 & 0,018 & 1,00 & 0,018 & 0,056 \\
\hline 7,0 & 0,020 & 0,020 & 1,89 & 0,133 & 0,012 & 1,00 & 0,012 & 0.091 \\
\hline 8,0 & 0,026 & 0,040 & 1,89 & 0,152 & 0,022 & 1,00 & 0,022 & 0,050 \\
\hline 9,0 & 0,029 & 0,029 & 1,91 & 0,171 & 0,020 & 1,00 & 0,020 & 0,067 \\
\hline 10,0 & 0,024 & 0,029 & 1,93 & 0,190 & 0,021 & 1,00 & 0,021 & 0,059 \\
\hline 11,0 & 0,024 & 0,018 & 1,93 & 0,209 & 0,017 & 1,00 & 0,017 & 0,091 \\
\hline 12,0 & 0,026 & 0,027 & 1,95 & 0,229 & 0,024 & 1,00 & 0,024 & 0,082 \\
\hline 13,0 & 0,015 & 0,009 & 1,94 & 0,248 & 0,011 & 1,00 & 0,011 & 0,192 \\
\hline 14,0 & 0,010 & 0,012 & 1,96 & 0,268 & 0,012 & 1,00 & 0,012 & 0,221 \\
\hline 15,0 & 0,013 & 0,006 & 1,98 & 0,288 & 0,009 & 1,00 & 0,000 & 0,215 \\
\hline 16,0 & 0,017 & 0,008 & 1,97 & 0,308 & 0,013 & 1,00 & 0,013 & 0,179 \\
\hline 17,0 & 0,011 & 0,006 & 1,98 & 0,328 & 0,010 & 1,00 & 0,010 & 0,248 \\
\hline 18,0 & 0,005 & 0,007 & 1,98 & 0,348 & 0,008 & 1,00 & 0,000 & 0,419 \\
\hline 19,0 & 0,004 & 0,005 & 1,99 & 0,368 & 0,006 & 1,00 & 0,000 & 0,550 \\
\hline 21,0 & 0,004 & 0,005 & 1,98 & 0,408 & 0,007 & 2,00 & 0,000 & 0,550 \\
\hline
\end{tabular}

Thus, the test showed that the soil subsidence of gravity load was $0.252 \mathrm{~m}$ or $25.20 \mathrm{~cm}$. The soaking soil refers to type II [6].However, the customer decides to abandon costly decisions on pile-sinking. He assumes the risk of an emergency condition with possible soaking. And it is quite possible that these hopes are real. Moreover, in the event of possible deformations, the progressive designer will prescribe a system of geotechnical monitoring of the controlled parameters. However, the basis for the state expert examination of project documentation should be a regulatory document, that is territorial construction standards.

These standards exist in Moscow and in the Leningrad Region. The nearest regulatory documents to the south of the Krasnoyarsk Territory are in the Tomsk Region. And if the "small" Khakassia cannot allow the development of such standards, then the vast Krasnoyarsk Territory should develop such standards and Khakassia's geotechnicians can contribute to the results of geotechnical monitoring at the facilities located in the Republic and in the South of the Krasnoyarsk Territory. 


\subsection{Analysis of the work of experimental objects located on the heaving soils.}

However, the greatest danger in the Republic of Khakassia is not the subsiding soils, not the fear of them among the designers, but the danger from the frost heaving of the soils, which especially arises during the construction period. This fear leads designers to eliminate this danger by sinking piles at those points where it is possible to use foundations on the natural base. One of the reasons why designers are afraid of frost heaving is that the criteria for heaving assessment are not objective. So, three levels for the analysis of soils heaving, presented in the landmark work of Nevzorov, are of undoubted interest [7,8]. However, for most designers, the main document is a report on engineering and geological surveys, where almost all the soils with possible autumn soaking are regarded as heaving, though laboratory experiments do not show this.

The years of experience in expert study of the causes for the occurrence of an emergency condition of buildings and structures show that in the conditions of the Minusinsk Hollows the frost heaving especially during construction is more dangerous than subsidence. Therefore, if the soil has moved from the subsiding to the non-subsiding type in the result of preliminary or organized soaking, then according to the experts of the survey organizations and designers, it will become a heaving one. However, this is not what occurs in practice. The frost heaving reliably develops when there is a recharge from ground waters. Of course, with increased natural humidity, when the index of liquidity exceeds zero mark, the process of migration and frost heaving is underway. But the coefficient of water accumulation in this case (without recharge from ground waters) is much lower (Figure 4).

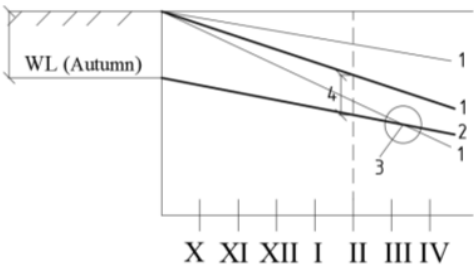

1- Possible trends depending on the speed of soil freezing; 2 - trend of ground water level;

3 - overlap by the freezing point of the position of the ground water level;

4 - distance from freezing point to ground water level.

Fig. 4. Chart of freezing and ground water level in winter

This chart shows the lowering of the surface water at the end of autumn and throughout winter. The main reasons in this case are snow precipitations which do not lead to the filling of soil interstices with water, and freezing of the surface [9]. Depending on the temperature of the outside air, there is a change in the speed of freezing of the foundation soil [10].

\subsection{Research methodology of frost heaving and cryogenic structures}

The laboratory studies of cryogenic textures in the conditions of frost heaving were carried out in the portable ground trays and in the stationary ground tray. It is established that the most effective cryogenic migration occurs under the slow freezing in the conditions of high negative temperatures (not lower than $-3^{\circ} \mathrm{C}$ ). To study the frost heaving and the formation of a cryogenic texture at the border of the soils both treated with $\mathrm{KCl}$ and non-treated, the experiments were carried out according to the following procedure: a layer of $100 \mathrm{~mm}$ sand soil was placed on a gravel drainage pad; the treated $\mathrm{KCl}$ soil was tightly placed through the polyethylene film, which was then removed; the tray was taken out to the open space at negative temperatures for four days; after freezing the body of frozen soil was opened and sawn at negative temperatures to expose the cryogenic texture [11-12]. 
Figure 5 shows one of the typical schemes for the formation of cryogenic textures on the contact of treated and non-treated soils.

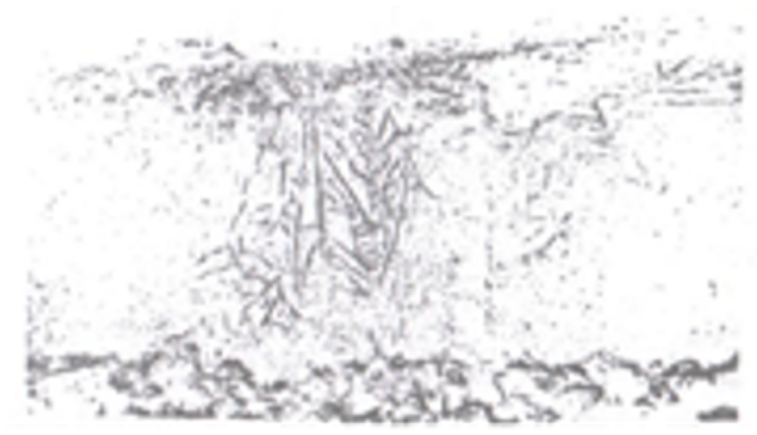

Fig. 5. A cryogenic texture in a layer contact area obtained in $1980 \mathrm{~s}$.

The treated soil (on the left) has a massive cryogenic texture. The non-treated one has a stratified texture with horizontal ice lenses. At the point of contact there are vertical and inclined ice lenses.

When discussing the results with Professor I.A. Tyutyunov we came to the conclusion that the vertical ice lenses were formed due to the advance freezing [13] of the treated soil and the formation of the freezing front of the non-treated soil at the phase boundary in the horizontal direction. A similar texture can be formed at the boundary of the tense zones below the bottom of the foundation.

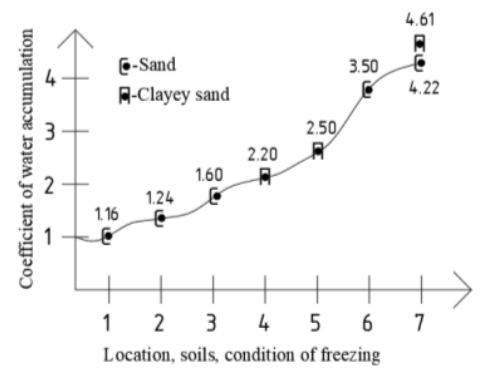

Fig. 6. A plot of moisture redistribution (coefficient of water accumulation) at frost penetration in different conditions.

Below is the information on the conditions of soils freezing at the facilities according to Figure 6.

1)In the freezer with a constant negative temperature;

2)In a soil hood in the open air;

3)In the stationary soil pan during natural freezing and artificial thawing in the period of negative temperatures;

4) Under the foundation base in Vilners house, Minusinsk;

5)Under the foundation base in 27, Vyatkina str. in Abakan during freezing from the basement;

6)In a field site during freezing below the groundwater level;

7) A site of geo-engineering investigations for a residential house, 2, Katernaya str. in Abakan; clayey sand lies at $0,4-0,8 \mathrm{~m}$ from the ground surface, silty sand - at the depth of $0,8-1,8 \mathrm{~m}$ underlain by gravel, the groundwater level is $3 \mathrm{~m}$.

The study of the effects of frost heaving on the deformations of buildings has been conducted for a long time. The list of observed objects is presented in table 2 . 
Table 2. Results of expert investigations of coil deformed by frost heave under building and structures.

\begin{tabular}{|c|c|c|c|c|}
\hline Location/floor & $\begin{array}{l}\text { Construction } \\
\text { scheme }\end{array}$ & Soil & $\begin{array}{c}\text { Groundwater } \\
\text { level from } \\
\text { designed/from } \\
\text { basement floor }\end{array}$ & $\begin{array}{c}\text { Stress/soil } \\
\text { parameters }\end{array}$ \\
\hline $\begin{array}{c}\text { State Technical } \\
\text { College - 59, } \\
\text { Abakan / } 2 \text { floor, } \\
\text { basement }\end{array}$ & $\begin{array}{c}\text { Frame; foundation } \\
\text { posts } 0,85 \times 0,85\end{array}$ & $\begin{array}{l}\text { Gravel with } \\
\text { silty - clayey } \\
\text { filling }\end{array}$ & $3,5 / 1,0$ & $\begin{array}{l}0,55 / \text { partly } \\
\text { collapsed }\end{array}$ \\
\hline $\begin{array}{c}\text { Kindergaten, } \\
\text { Zeleny / } 2 \text { floors }\end{array}$ & Walls & Clayey sand & $4.5 / 1,5$ & $\begin{array}{c}0,20 / \text { more than } \\
10 \mathrm{~mm}\end{array}$ \\
\hline $\begin{array}{c}\text { Prikholmye } \\
\text { Secondary } \\
\text { General Education } \\
\text { School No.4, } \\
\text { settlement } \\
\text { Prikholmye/ } 2 \\
\text { floor, basement } \\
\end{array}$ & Walls & Loam & 3,0 & $\begin{array}{c}0,20 / \text { up to } 12 \\
\mathrm{~mm}\end{array}$ \\
\hline $\begin{array}{c}\text { Askiz, residential } \\
\text { house, Khakasia/ } \\
1 \text { floor }\end{array}$ & $\begin{array}{l}\text { Longitudinal } \\
\text { bearing walls; strip } \\
\text { foundations }\end{array}$ & Clayey sand & 1,7 & $0 /$ up to $8 \mathrm{~mm}$ \\
\hline $\begin{array}{l}\text { District hospital } \\
\text { Shira/ } 2 \text { floor }\end{array}$ & $\begin{array}{c}\text { Longitudinal } \\
\text { bearing walls; strip } \\
\text { foundations } \\
\end{array}$ & Clayey sand & $5 / 4,0$ & $0,20 /$ up to $8 \mathrm{~mm}$ \\
\hline $\begin{array}{l}\text { Supply depot, } 18, \\
\text { Itygina str., } \\
\text { Abakan / } 1 \text { floor }\end{array}$ & Walls & Clayey sand & $3,5 / 3,0$ & $0,20 /$ up to $3 \mathrm{~mm}$ \\
\hline $\begin{array}{l}\text { 27, Vyatkina str. } \\
\text { Abakan/ } 2 \text { floors, } \\
\text { basement }\end{array}$ & Walls & Silty sand & $4,5 / 2,5$ & $\begin{array}{c}0,10 / \text { more than } \\
10 \mathrm{~mm}\end{array}$ \\
\hline $\begin{array}{l}\text { Vilner House, } \\
\text { Minusinsk/ } 3 \\
\text { floor, basement }\end{array}$ & Walls & Silty sand & $4.5 / 1,5$ & $0,20 /$ up to $5 \mathrm{~mm}$ \\
\hline $\begin{array}{c}\text { Heated parking, } \\
\text { Shira, Lineynaya } \\
\text { str./ } 1 \text { floor }\end{array}$ & Frame & $\begin{array}{l}\text { Sandy clay } \\
\mathrm{I}_{\mathrm{L}}=0,5-0,6\end{array}$ & $5,5 / 5,5$ & $\begin{array}{l}0,22 / \text { up to } 5 \mathrm{~mm} \\
\text { in concrete } \\
\text { floors }\end{array}$ \\
\hline
\end{tabular}

The analysis of the materials presented in the table shows that the pressures under the bottom of foundation of the collapsed part of the GPTU-59 building [14] reached $0.55 \mathrm{mPa}$, but this did not lead to a decrease in the migration process [15], the soil received additional moisture while and lost stability during thawing. It is necessary to pay attention to the fact that in the second half of the building with the concrete floors in the basement, the loss of stability - protrusion of soil from the bottom of foundation was substantially lower. This is due to the fact that the beginning of the process of soil protrusion was stopped by a concrete floor, which resisted the movement of the soil being squeezed out from below. As a result, the concrete floor was raised to a height of $65 \mathrm{~mm}$.

Between the fragments of the concrete floor there appeared a crack of up to one hundred millimeters, where one could fit a hand to a depth of up to $350 \mathrm{~mm}$.

The kindergarten in the village Zelenoe was also in an emergency condition during the construction period, the pressure under the bottom did not exceed $0.2 \mathrm{mPa}$, but the deformations in the walls, particularly the crack opening exceeded $10 \mathrm{~mm}$.

The basement wall blocks received a distinct inclination. The customer agreed to fill the basement with soil. This block - section has been currently in operation for more than 30 
years. The similar emergency condition occurred in the village Priholmye [16]. There, during the construction period, the pressure under the bottom did not exceed $0.1 \mathrm{mPa}$, however, the foundation during the thawing period inclined more than in the above described example. However, during the period of operation, the soils stabilized and this object is still in use. It is worth noting that the deformation of the frost heaving [17-19] in the village Priholmye is lower than that described above, but one conclusion can be made: it is impossible to suppress the frost heaving of the soil on the excessively heaving soils of the Minusinsk Hollows by loading and pressing the soil under the bottom of the foundations.

\section{Conclusion}

The presented materials, the analysis of emergency facilities show that even in excessively - heaving soils, the danger of impact of cryogenic processes on the foundations can be excluded. So, the eastern part of the GPTU 59 facility has maintained a healthy state. In the case of presence of reinforcement grid in the concrete floors, the breaking of concrete in the floors could be avoided. Under the concrete floor it was possible to make a reliable thermal insulation, but when the collapse occurred in 1983, the builders did not have the ability to carry out conservation of objects with expensive thermal insulation solutions during the winter construction period.

At the present time, such insulation is necessary not only as an anti-abrasion stabilization, but also as a thermal protection technology while mounting the heated floors.

The use of pile foundations for both subsiding and heaving soils is not the most rational solution. If the negative friction affects the piles in the subsiding soils, then the tangential forces of frost heaving also negatively affect their bearing capacity in the heaving soils.Thus, in practical terms, these soils are united by the designers' fear of their poor knowledge of the work with the soils and the possible inaccuracy of engineering and geological survey materials. The method of organized soaking, implemented in the village Solontsy, as well as methods of anti-heave stabilization, shows the relevance of rejecting expensive driven piles.

\section{References}

1. L. Kochurova, V. Eliseev. Human ecology. Ecological situation in Khakassia. 15, 10 (2011).

2. A. Gerasimova. The climate of Abakan, Leningrad Gidrometeoizdat, 42 (1985)

3. A. Budikova, N. Otepbergen. Problems of science. Engineering and geological studies of loess subsidence deposits. 43, 4 (2018).

4. A. Bogomolov, Yu Olyanskii, E. Shchekochikhina, I. Kuzmenko. Bulletin of Perm National Research Polytechnic University. Construction and architecture. Features of deformation behavior, slow subsidence of loess soils in the foundations of engineering structures in the man-made flooding. 3, 34 (2016).

5. Yu. Kozakov, N. Bulankin, G. Shishkanov, V. Korol. Specific features of the use of piles in Eastern Siberia. 268 p. (1992).

6. Rules and regulations 22. 13330.2016. Foundations of buildings and structures. Updated edition of Construction rules and regulations 2.02.01-83*. p. 6.1 .13 (2017)

7. A. Nevzorov. Foundations on seasonally freezing soils. 67 (2000).

8. H. Rathmayer. Frost in geotechnical engineering: Int. Symp. 1,2, 34 (1989).

9. S. Kudryavtsev. Scientific reports. Effect of migration moisture on the frost heaving process of seasonally freezing soils. 233 (2003). 
10. S. Kudryavtsev. Modern technologies. System analysis. Modeling. Numerical simulation of the process of frost heaving and thawing depending on the speed of soil freezing. 2, 105 (2012).

11. O. Khalimov. The Method of Pysical - Chemical Anti - Heave Stabilization of Soils during Construction in case of High Ground Water Level. Synopsis of PhD Thesis. 23 (1989).

12. S. Kudriavtsev. Freezing and defrosting soil. Series «Progress modern geotechniks». 116 (2014).

13. I. Tyutyunov, O. Khalimov. Anti-shock stabilization in the fight against subsidence of thawing soils, Proceedings of the institute. 118 (1986).

14. O. Khalimov. Soil - Struc. Inter. Underg. Struct. and Reta. Wal. Methods of Research on Frost Heave of Soil and Foundation - Freezing Soil Bulk Interaction in Terms of Seasonal Deep Frost Penetration including Areas of Pressure Migration. 1, 133 (2014).

15. V. Puskov. Thesis research. Force impacts of frost heaving of soils on the foundations of structures and methods for their calculation. 1, 65 (1995).

16. O. Khalimov, D. Strelnikov. : AIP Conference Proceedings. Geotechnical consulting at the stages of design and full repair: A case study of village school in Minusinsk region, Russia. 1899, (2017).

17. T. L. Wang, Z. R. Yue, T. C. Sun, and J. C. Hua, Sciences in Cold and Arid Regions, 7, 407-413 (2015).

18. A. Sato and T. Yamanashi, Proceedings of the ISSMGE Technical Committee 207 Int. Conf. on Geotech. Eng. 4, 366-373 (2015).

19. A. J. J. Pauderham, Development of Cities and Geotechnical Construction, 11, 211-221 (2007) 